\title{
PENGARUH DANA PIHAK KETIGA, MARGIN KEUNTUNGAN, SERTIFIKAT WADIAH BANK INDONESIA, RETURN ON ASSET, DAN NON PERFORMING FINANCING TERHADAP PEMBIAYAAN MURABAHAH PADA BANK SYARIAH MANDIRI DAN BANK MUAMALAT INDONESIA PERIODA 2009-2013
}

\author{
Rizqi Amalia \\ Khusnul Hidayah
}

\begin{abstract}
Islamic banks have the same functionality conventional banks as intermediaries of financial services (financial intermediary), has a fundamental duty to collect funds from the public and channeled back to the community in the form of financing facilities. Fund raising is done through savings and investments such, wadiah deposits, savings and time deposits. The distribution of funds is done with some kind of contract as, murabahah, istishna, mudharabah, musyarakah, ijarah, and salam. The purpose of this research is to determine the effect of Third party funds (DPK), profit margin, wadiah certificate of Indonesian Bank (SWBI), return on assets (ROA), and non performing financing (NPF) to murabahah financing. Object in the reserach is Bank Syariah Mandiri and Bank Muamalat Indonesia period 2009-2013. The result of analysis showed by simultan DPK, profit margin, SWBI, ROA, and NPF effect to murabahah financing. Predictive ability of the five variables to financing is $98.7 \%$ which is indicated by the amount of adjusted $R 2$ and the rest is influenced by other variables. DPK, and ROA partially positive effect to murabahah financing. SWBI negatively affect to murabahah financing. The profit margin is not a positive influence to murabahah financing and NPF does not negative affect to murabahah financing.
\end{abstract}

Keywords: Murabahah Financing, Third Party Funds (DPK), profit margin, Wadiah Certificate of Indonesian Bank (SWBI), Return on Assets (ROA), and Non Performing Financing (NPF).

\section{PENDAHULUAN}

Bank syariah merupakan lembaga keuangan yang bertugas menghimpun dana dari masyarakat serta menyalurkan kembali kepada masyarakat dalam bentuk pembiayaan dengan mekanisme tertentu. Penghimpunan dana dilakukan melalui simpanan dan investasi seperti giro wadiah, tabungan dan deposito berjangka. Sedangkan penyaluran dana dilakukan dengan beberapa macam akad, seperti murabahah, istishna, mudharabah, musyarakah, ijarah, dan salam. Indikator utama untuk mengukur perkembangan bank syariah di Indonesia salah satunya dengan melihat besarnya jumlah pembiayaan yang disalurkan oleh bank syariah kepada 
nasabah. Pembiayaan yang dominan bagi perbankan syariah di dunia adalah pembiayaan murabahah. Pembiayaan murabahah di Indonesia sampai saat ini mencapai 60\% (contan.co.id). Menurut Sri dan Wasilah (2008:168) pembiayaan murabahah adalah pembiayaan berdasarkan akad jual beli antara bank dan nasabah.

Bank yang akan digunakan dalam penelitian ini adalah Bank Syariah Mandiri dan Bank Muamalat Indonesia, karena bank tersebut memiliki tingkat aset dan laba yang terbesar dan data laporan keuangan perbankan syariah bukan unit usaha syariah. Dilihat dari data Bank Syariah Mandiri memiliki aset sebesar Rp54,2 triliun dan laba sebesar Rp805,6 milyar pada tahun 2012 dan Bank Muamalat Indonesia memiliki aset sebesar Rp44,9 triliun dan laba sebesar Rp389,4 milyar pada tahun 2012 (www.keuangankontan.co.id).

Banyak faktor yang mempengaruhi bank dalam menyalurkan pembiayaannya, baik faktor internal maupun faktor eksternal dari bank itu sendiri. Adapun beberapa rasio keuangan yang sering digunakan untuk menilai kondisi internal perusahaan antara lain, rasio permodalan bank yang diwakili oleh rasio capital adequacy ratio (CAR), rasio profitabilitas bank yang diwakili oleh return on asset (ROA), dan rasio likuiditas bank yang diwakili oleh dana pihak ketiga (DPK).

Sebagai lembaga keuangan, maka dana merupakan masalah utama bagi setiap bank. Tanpa dana yang cukup, bank tidak dapat berfungsi dengan baik. Anggraini (2005) dalam Nurbaya (2013) menjelaskan bahwa dana pihak ketiga dapat mempengaruhi budget bank. Jika dana dari pihak ketiga bertambah, maka budget bank tersebut akan bertambah pula. Budget suatu bank berhubungan dengan jumlah dana yang dimiliki oleh bank tersebut. Dana yang ada akan dialokasikan oleh bank dalam berbagai bentuk termasuk untuk pembiayaan. Penelitian Maula (2009) menunjukkan bahwa DPK berpengaruh negatif terhadap pembiayaan murabahah. Sedangkan Siregar (2005) mengatakan DPK berpengaruh positif terhadap pembiayaan murabahah.

Marjin keuntungan salah satunya diperoleh dari transaksi jual beli (murabahah). Febriana (2013) memaparkan bahwa pembiayaan murabahah dengan prinsip mark-up financing mempunyai persamaan dengan kredit atau kontrak utang dari bank konvensional. Penelitian mengenai marjin keuntungan antara Oktavina 
(2011) dan Febriana (2013) menghasilkan hasil yang berbeda. Hasil penelitian Oktavina (2011) menunjukkan marjin keuntungan berpengaruh positif terhadap pembiayaan murabahah, sedangkan Febriana (2013) menunjukkan pengaruh negatif terhadap pembiayaan murabahah.

Bank Indonesia menerbitkan sertifikat wadiah Bank Indonesia (SWBI) yang dapat digunakan untuk menyimpan dana jangka pendek bagi bank syariah yang kelebihan likuiditas dengan prinsip wadiah atau titipan yang pengambilannya dilakukan setelah jangka waktu penitipan dana wadiah berakhir. Hal ini dilakukan oleh Bank Indonesia agar kebijakan moneter dapat berjalan sesuai dengan prinsip syariah. Siregar (2005) dalam Nurapriayani (2009) mengemukakan bahwa pada saat tertentu, SWBI menarik bagi perbankan syariah untuk menanamkan dananya pada instrumen ini dibandingkan disalurkan melalui pembiayaan karena adanya berbagai faktor, diantaranya faktor risiko. Variabel SWBI pada penelitian terdahulu mengalami inkonsistensi hasil. Ismoyowati (2013) dalam penelitiannya SWBI berpengaruh negatif sedangkan Febriana (2013) mengatakan SWBI berpengaruh positif terhadap pembiayaan.

Analisis return on asset (ROA) dalam analisis keuangan mempunyai arti yang sangat penting sebagai salah satu teknik analisis yang lazim digunakan untuk mengukur efektivitas dari keseluruhan operasi perusahaan. ROA merupakan suatu pengukuran manajeman dalam memperoleh keuntungan secara keseluruhan. Penelitian Saputro (2012) berbeda dengan penelitian Nurbaya (2010), Saputro (2012) menyatakan bahwa ROA tidak berpengaruh terhadap pembiayaan sedangkan Nurbaya (2013) berpengaruh terhadap pembiayaan murabahah.

Nusantara (2009) dalam Pratiwi (2012) salah satu indikator yang menunjukkan kerugian akibat risiko kredit adalah tercermin dari besarnya non performing Loan (NPL), dalam terminologi bank syariah disebut non performing financing (NPF). NPF adalah rasio antara pembiayaan yang bermasalah dengan total pembiayaan yang disalurkan oleh bank syariah. Berdasarkan kriteria yang sudah ditetapkan oleh Bank Indonesia kategori yang termasuk dalam NPF adalah pembiayaan kurang lancar, diragukan dan macet. Variabel NPF dari penelitian Maula (2010) berpengaruh negatif terhadap pembiayaan murabahah sedangkan 
penelitian Nurhasanah (2010) berpengaruh positif terhadap pembiayaan murabahah.

Berdasar latar belakang masalah, peneliti tertarik untuk melakukan penelitian lebih lanjut terhadap faktor-faktor yang mempengaruhi pembiayaan murabahah. Penelitian ini menguji pengaruh dana pihak ketiga, marjin keuntungan, sertifikat wadiah Bank Indonesia, return on asset, dan non performing financing terhadap pembiayaan murabahah pada Bank Syariah Mandiri dan Bank Muamalat Indonesia peroide 2009-2013.

\section{TINJAUAN PUSTAKA}

\section{Pembiayaan Murabahah}

Pengertian pembiayaan secara luas, berarti financing atau pembelanjaan, yaitu pendanaan yang dikeluarkan untuk mendukung investasi yang telah direncanakan, baik dilakukan sendiri maupun dijalankan oleh orang lain. Pembiayaan dalam arti sempit dipakai untuk mendefenisikan pendanaan yang dilakukan oleh lembaga pembiayaan, seperti bank syariah kepada nasabah. Pengertian pembiayaan berdasarkan prinsip syariah adalah menyediakan uang atau tagihan lain yang dipersamakan dengan berdasarkan persetujuan atau kesepakatan antar bank dengan pihak lain yang mewajibkan pihak yang dibiayai untuk mengembalikan uang atau tagihan tersebut setelah jangka waktu tertentu dengan imbalan bagi hasil.

Bank syariah dirancang untuk terbinanya kebersamaan dalam menanggung resiko usaha dan berbagi hasil usaha antara pemilik dana (shahibul maal) yang menyimpan uangnya di bank dengan bank selaku pengelola dana (mudharib), dan di sisi lain bank selaku pemilik dana dengan masyarakat yang membutuhkan dana baik yang berstatus pemakai dana maupun pengelola usaha (mudharib) (Febriana, 2013). Pembiayaan murabahah adalah akad jual beli barang dengan menyatakan harga perolehan dan keuntungan (marjin) yang disepakati oleh penjual dan pembeli. 


\section{Pengembangan Hipotesis}

\section{Dana Pihak Ketiga (DPK)}

DPK merupakan dana yang berhasil dikumpulkan oleh bank dari masyarakat yang sewaktu-waktu dapat ditarik kembali. Nurbaya (2013) dalam penelitiannya menyebutkan bahwa DPK berpengaruh positif dan signifikan terhadap pembiayaan murabahah, artinya semakin banyak dana yang dihimpun oleh bank syariah maka semakin tinggi penyaluran dana yang dilakukan oleh bank syariah dalam hal pembiayaan murabahah, hasil penelitian menyimpulkan bahwa DPK berpengaruh positif dan signifikan terhadap penyaluran dana. Berdasar uraian tersebut dan penelitian terdahulu yang sudah dilakukan, maka hipotesis kedua yang diajukan dalam penelitian ini adalah:

$\mathrm{H}_{1}$ : Dana pihak ketiga berpengaruh positif terhadap pembiayaan murabahah.

\section{Marjin Keuntungan}

Muhammad dalam Mufidah (2012) menyatakan bahwa marjin keuntungan dalam murabahah dapat ditetapkan sedemikian rupa sehingga memastikan bank dapat memperoleh keuntungan yang sebanding dengan keuntungan bank-bank berbasis bunga yang menjadi saingan bank-bank Islam. Penelitian Mufidah (2012) menyatakan bahwa marjin keuntungan berpengaruh positif dan signifikan terhadap pembiayaan murabahah. Sama halnya dengan penelitian Ismoyowati (2013) bahwa marjin keuntungan berpengaruh positif terhadap pembiayaan murabahah. Semakin tinggi keuntungan yang diperoleh suatu bank maka semakin banyak pembiayaan yang disalurkan oleh bank. Berdasar uraian tersebut dan penelitian terdahulu yang sudah dilakukan, maka hipotesis kedua yang diajukan dalam penelitian ini adalah: $\mathrm{H}_{2}$ : Marjin keuntungan berpengaruh positif terhadap pembiayaan murabahah.

\section{Sertifikat Wadiah Bank Indonesia (SWBI)}

Terkait dengan pembiayaan murabahah bank syariah diwajibkan mengasuransikan dananya. Bank syariah dalam hal ini tidak mendapatkan bunga, tapi mendapatkan bonus yang tidak boleh diperjanjikan di muka. Apabila bonus yang ditawarkan SWBI lebih menarik dari tingkat bagi hasil pada pembiayaan maka bank menginvestasikan dananya dalam bentuk SWBI (Nurapriyani, 2009). 
SWBI menarik bagi perbankan syariah untuk menanamkan dananya dibandingkan disalurkan melalui pembiayaan, karena adanya berbagai faktor risiko, sehingga SWBI berpengaruh negatif terhadap pembiayaan, semakin besar SWBI maka semakin sedikit pembiayaan yang disalurkan (Ismoyowati, 2013).

Ismoyowati (2013) dalam penelitiannya SWBI berpengaruh negatif terhadap pembiayaan murabahah. Berdasar uraian tersebut dan penelitian terdahulu yang sudah dilakukan, maka hipotesis kedua yang diajukan dalam penelitian ini adalah:

$\mathrm{H}_{3}$ : Sertifikat Wadiah Bank Indonesia berpengaruh negatif terhadap pembiayaan murabahah.

\section{Return on Asset (ROA)}

Semakin besar tingkat keuntungan (ROA) yang didapatkan oleh bank, maka semakin besar upaya manajemen menginvestasikan keuntungan tersebut dengan berbagai kegiatan yang menguntungkan manajemen, terutama dengan penyaluran pembiayaan. Selain itu semakin besar suatu bank menghasilkan laba, berarti bank sudah efektif dalam mengelola asetnya. Penelitian Nurbaya (2013) menunjukkan variabel ROA berpengaruh positif terhadap pembiayaan murabahah. Berdasar uraian tersebut dan penelitian terdahulu yang sudah dilakukan, maka hipotesis kedua yang diajukan dalam penelitian ini adalah:

$\mathrm{H}_{4}$ : Return on asset berpengaruh positif terhadap pembiayaan murabahah.

\section{Non Performing Financing (NPF)}

Kredit bermasalah merupakan hal yang tidak menggembirakan bagi pihak bank. Menurut Dendawijaya (2005) dalam Pratiwi (2012) hal ini disebabkan oleh kegagalan pihak debitur memenuhi kewajibannya untuk membayar angsuran (cicilan) pokok kredit beserta bunga yang telah disepakati kedua belah pihak dalam perjanjian kredit. Semakin besar NPF yang dimiliki bank maka semakin sedikit pembiayaan yang disalurkan. Kredit bermasalah yang tinggi dapat menimbulkan keengganan bank untuk menyalurkan kredit karena harus membentuk cadangan penghapusan yang besar. Jika hal ini berlangsung secara terus menerus akan mengurangi modal bank. NPF akan mempengaruhi jumlah modal maka secara logika peningkatan NPF mempengaruhi jumlah pembiayaan dan menurunkan nilai 
profitabilitas bank (Nurapriyani, 2009).

Variabel NPF dari penelitian Maula (2010) menunjukkan pengaruh negatif terhadap pembiayaan murabahah. Berdasar uraian tersebut dan penelitian terdahulu yang sudah dilakukan, maka hipotesis kedua yang diajukan dalam penelitian ini adalah:

H5: Non performing financing berpengaruh negatif terhadap pembiayaan murabahah.

\section{Model Penelitian}

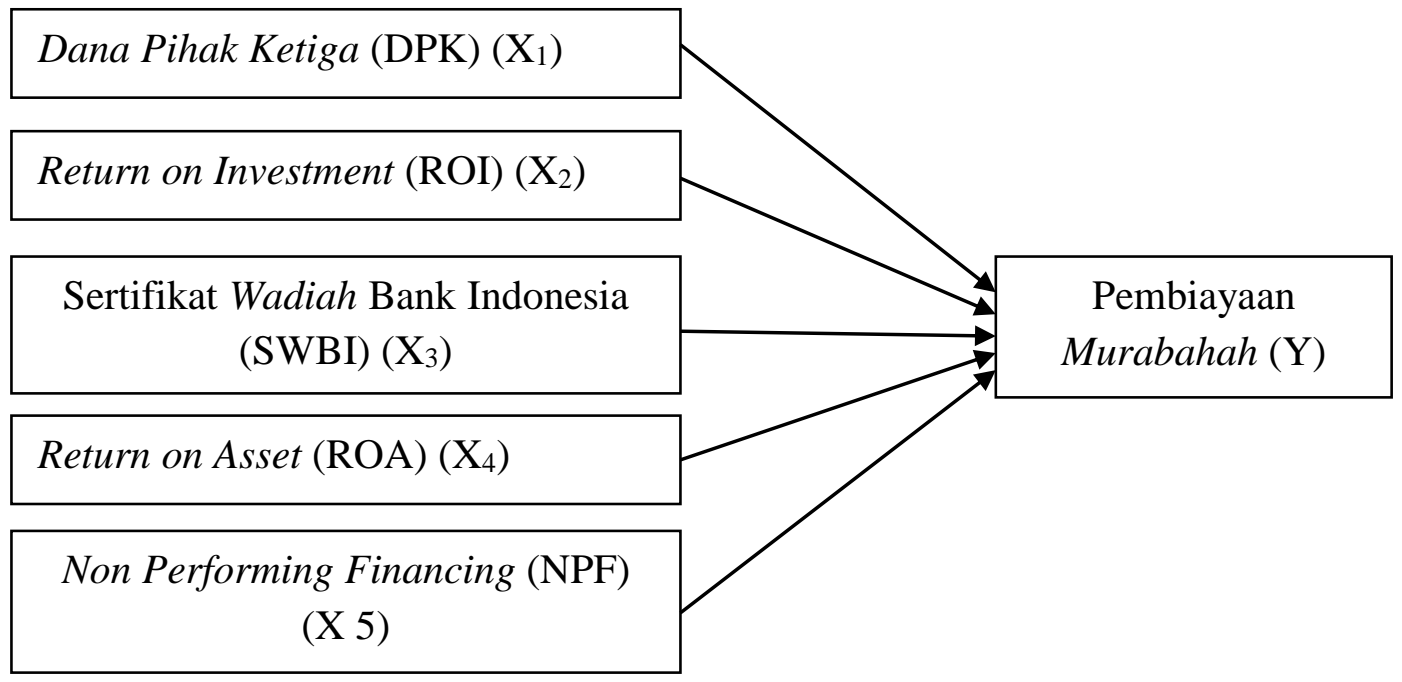

Gambar 1

Model Penelitian

\section{METODA PENELITIAN}

\section{Objek Penelitian}

Objek dalam penelitian ini adalah Bank Syariah Mandiri dan Bank Muamalat Indonesia. Alasan dipilihnya Bank Syariah Mandiri dan Bank Muamalat Indonesia karena kedua bank tersebut merupakan perbankan syariah. Kedua bank tersebut juga memiliki tingkat aset dan labayang terbesar dibandingkan bank syariah lainnya.

\section{Pengukuran Variabel}

\section{Variabel Dependen}

Pembiayaan murabahah adalah transaksi jual beli, bank bertindak sebagai 
penjual dan nasabah sebagai pembeli, dengan penentuan harga jual yaitu harga beli bank dari pemasok ditambah keuntungan (marjin), sesuai dengan kesepakatan antara pihak bank dengan nasabah sehingga pembiayaan murabahah dihitung dengan logaritma natural. Bentuk logaritma digunakan karena pada umumnya nilai pembiayaan murabahah sangat besar, maka untuk menyeragamkan nilai dengan variabel lainnya, nilai pembiayaan murabahah diubah dalam bentuk logaritma terlebih dahulu (www.bi.go.id).

Pembiayaan Murabahah = Ln Piutang Murabahah

\section{Variabel Independen}

\section{Dana Pihak Ketiga (DPK)}

DPK adalah dana yang berhasil dikumpulkan oleh bank dari masyarakat yang merupakan sumber dana terpenting bagi kegiatan operasional suatu bank (Febriana, 2013). Pengukuran DPK yaitu dengan penjumlahan dari giro wadiah, tabungan wadiah, deposito mudharabah, dan tabungan mudharabah dengan satuan ketetapan berbentuk rupiah, sehingga DPK dihitung dengan logaritma natural. Bentuk logaritma digunakan karena pada umumnya nilai DPK sangat besar, maka untuk menyeragamkan nilai dengan variabel lainnya, nilai DPK diubah dalam bentuk logaritma terlebih dahulu (www.bi.go.id).

$$
\text { DPK }=\text { Ln }(\text { Tabungan }+ \text { Giro }+ \text { Deposito })
$$

\section{Marjin Keuntungan}

Marjin keuntungan merupakan keuntungan yang diperoleh dari hasil alokasi pembiayaan dalam bentuk jual beli murabāhah dengan kesepakatan antara penjual dan pembeli, dalam hal ini bank sebagai penjual sedangkan nasabah sebagai pembeli, sehingga marjin keuntungan dihitung dengan logaritma natural. Bentuk logaritma digunakan karena pada umumnya nilai marjin keuntungan sangat besar, maka untuk menyeragamkan nilai dengan variabel lainnya, nilai marjin keuntungan diubah dalam bentuk logaritma terlebih dahulu (www.bi.go.id).

Marjin Keuntungan = Ln Pendapatan Marjin Murabahah 


\section{Sertifikat Wadiah Bank Indonesia (SWBI)}

Sertifikat Wadiah Bank Indonesia adalah salah satu alat yang digunakan untuk penyerapan kelebihan likuiditas yang dialami oleh perbankan Islam, sehingga SWBI dihitung dengan logaritma natural. Bentuk logaritma digunakan karena pada umumnya nilai SWBI sangat besar, maka untuk menyeragamkan nilai dengan variabel lainnya, nilai SWBI diubah dalam bentuk logaritma terlebih dahulu (www.bi.go.id).

Sertifikat $\underline{\text { Wadiah }}$ Bank Indonesia $=$ Ln SWBI

\section{Return on Asset (ROA)}

Return on assets (ROA) merupakan salah satu rasio profitabilitas yang dapat mengukur kemampuan perusahaan dalam menghasilkan laba dari aktiva yang digunakan. ROA yang positif menunjukkan bahwa dari total aktiva yang dipergunakan untuk beroperasi (www.bi.go.id). Rumus yang digunakan yaitu:

$\mathrm{ROA}=\underline{\text { Laba Sebelum Pajak }}$ X 100\%

Total Asset

\section{Non Performing Financing (NPF)}

Non performing financing (NPF) adalah rasio antara pembiayaan yang bermasalah dengan total pembiayaan yang disalurkan oleh bank syariah. Berdasarkan kriteria yang sudah ditetapkan oleh Bank Indonesia kategori yang termasuk dalam NPF adalah pembiayaan kurang lancar, diragukan dan macet (www.bi.go.id). Rumus yang digunakan yaitu:

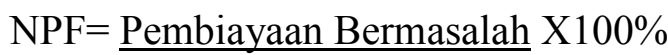
Total Pembiayaan

\section{ALAT ANALISIS DATA}

\section{Statistik Deskriptif}

Statistik deskriptif memberikan gambaran atau deskripsi suatu data yang dilihat dari nilai rata-rata (mean), maksimum dan minimum (Ghozali, 2011: 19). Statistik deskriptif bertujuan untuk mendapatkan gambaran ringkas dari sekumpulan data sehingga dapat menyimpulkan keadaan data secara mudah dan cepat. 


\section{Uji Asumsi Klasik}

\section{Uji Heteroskedastisitas}

Uji asumsi heteroskedastisitas bertujuan untuk menguji model regresi linier terjadi ketidaksamaan varian dari residual satu pengamatan ke lainnya. Jika varian dan residual satu pengamatan ke pengamatan lain tetap, maka disebut homoskedastisitas dan jika berbeda disebut heteroskedastisitas. Pengambilan keputusan ada tidaknya heteroskedastisitas (Ghozali, 2011: 139), sebagai berikut:

1) Jika ada pola tertentu seperti titik-titik yang ada membentuk suatu pola literatur (bergelombang, kemudian menyempit), maka terjadi heteroskedastisitas;

2) Jika tidak ada pola tertentu yang jelas serta titik-titik menyebar di atas dan di bawah angka 0 sumbu $\mathrm{Y}$, maka tidak terjadi heteroskedastisitas.

\section{Uji Multikolinieritas}

Uji multikolinieritas bertujuan untuk mengetahui model regresi masingmasing variabel bebas (independen) saling berhubungan secara linier. Model regresi yang baik adalah yang tidak terdapat korelasi linier/hubungan yang kuat antara variabel bebasnya. Menurut Ghozali (2011: 106) untuk mengukur multikolinieritas dapat dilihat dari nilai tolerance atau VIF (variance inflation factor) dari masing-masing variabel. Jika nilai toleransi $\leq 0,10$ atau VIF $\geq 10$ maka terdapat multikolinieritas, sehingga variabel tersebut harus dibuang atau sebaliknya.

\section{Uji Autokorelasi}

Uji autokorelasi bertujuan untuk menguji dalam suatu model regresi linier ada korelasi antara kesalahan pengganggu pada perioda t dengan kesalahan pengganggu pada perioda t-1 (Ghozali, 2011: 110). Pengambilan keputusan ada tidaknya autokorelasi, sebagai berikut:

1) Jika $0<\mathrm{d}<\mathrm{dl}$, maka tidak ada autokorelasi positif

2) Jika $\mathrm{dl} \leq \mathrm{d} \leq \mathrm{du}$, maka tidak ada autokorelasi positif

3) Jika 4-dl $<$ d $<4$, maka tidak ada autokorelasi negatif

4) Jika 4-du $\leq \mathrm{d} \leq 4$-dl, maka tidak ada autokorelasi negatif

5) Jika du $<\mathrm{d}<4$-dl, maka tidak ada autokorelasi negatif maupun autokorelasi positif 


\section{Uji Normalitas}

Uji normalitas bertujuan untuk menguji sebuah model regresi, variabel pengganggu, atau residual memiliki distribusi normal. Model regresi yang baik adalah distribusi normal atau mendekati normal. Dasar pengambilan keputusan memenuhi normalitas atau tidak dengan menggunakan uji Kolmogrov-Smirnov. Jika signifikansi pada nilai $K-S<0,05$ maka Ho ditolak, jadi data residual berdistribusi tidak normal. Jika signifikansi pada nilai $K-S>0,05$, maka Ho diterima, jadi data residual berdistribusi normal.

\section{Analisis Regresi Berganda}

Analisis regresi linier berganda adalah analisis untuk mengukur besarnya pengaruh antara dua atau lebih variabel independen terhadap satu variabel dependen dan memprediksi variabel dependen dengan menggunakan variabel independen. Data yang telah dikumpulkan dianalisis dengan menggunakan analisis regresi berganda dengan persamaan kuadrat terkecil biasa atau ordinary least square (OLS). Persamaan regresi yang dibentuk adalah:

$$
Y=\alpha+\beta_{1} X 1+\beta_{2} X_{2}+\beta_{3} X_{3}+\beta_{4} X_{4}+\beta_{5} X_{5}+e
$$

Keterangan:

$$
\begin{aligned}
\mathrm{Y} & =\text { Pembiayaan murabahah } \\
\alpha & =\text { konstanta } \\
\mathrm{X}_{1} & =\mathrm{DPK} \\
\mathrm{X}_{2} & =\text { Marjin keuntungan } \\
\mathrm{X}_{3} & =\mathrm{SWBI} \\
\mathrm{X}_{4} & =\mathrm{ROA} \\
\mathrm{X}_{5} & =\mathrm{NPF} \\
\mathrm{E} & =\text { residual }
\end{aligned}
$$

\section{Uji Hipotesis}

\section{Uji Determinasi $\left(\mathbf{R}^{2}\right)$}

Uji $\mathrm{R}^{2}$ pada intinya mengukur kemampuan model dalam menerangkan variasi variabel dependen. Nilai koefisien determinasi adalah antara nol dan satu. Nilai $\mathrm{R}^{2}$ yang kecil berarti kemampuan variabel-variabel indenpenden dalam menjelaskan 
variasi variabel dependen amat terbatas. Nilai yang mendekati satu berarti variabelvariabel independen memberikan hampir semua informasi yang dibutuhkan untuk memprediksi variasi variabel dependen (Ghozali, 2011: 97).

\section{Uji Signifikan Simultan (F)}

Menurut Ghozali (2011: 98) uji statistik F pada dasarnya menunjukkan variabel independen atau bebas yang dimasukkan dalam model mempunyai pengaruh secara simultan terhadap variabel dependen. Pengujian ini menggunakan uji $\mathrm{F}$, yaitu dengan melihat nilai $\mathrm{F}$ tabel dan $\mathrm{F}$ hitung pada output uji ANOVA. Jika $\mathrm{F}$ hitung $\leq \mathrm{F}$ tabel maka Ho diterima dan sebaliknya jika $\mathrm{F}$ hitung $>\mathrm{F}$ tabel maka Ho ditolak artinya bahwa variabel independen secara simultan berpengaruh terhadap variabel dependen.

\section{Uji Signifikansi Parameter Individual (t)}

Uji t digunakan untuk mengukur pengaruh satu variabel independen secara individual dalam menerangkan variasi variabel dependen. Uji ini dilakukan dengan syarat (Ghozali, 2011: 98):

1. Bila $\mathrm{t}$ hitung $<\mathrm{t}$ tabel maka $\mathrm{H}_{0}$ diterima dan ditolak $\mathrm{Ha}$, artinya bahwa variabel independen tidak berpengaruh terhadap variabel dependen;

2. Bila t hitung $>\mathrm{t}$ tabel, maka $\mathrm{H}_{0}$ ditolak dan menerima $\mathrm{Ha}$ artinya bahwa variable independen berpengaruh terhadap variabel dependen.

\section{HASIL DAN PEMBAHASAN}

\section{Statistik Deskriptif}

Statistik deskriptif memberikan gambaran atau deskripsi suatu data yang dilihat dari nilai rata-rata, maksimum dan minimum (Ghozali, 2011: 19). Statistik deskriptif bertujuan untuk mendapatkan gambaran ringkas dari sekumpulan data sehingga dapat menyimpulkan keadaan data secara mudah dan cepat. 
Tabel 1

Hasil Analisis Deskriptif (dalam jutaan rupiah)

\begin{tabular}{|l|l|r|r|r|}
\hline \multicolumn{1}{|c|}{ Variabel } & N & Minimum & Maksimum & Rata-rata \\
\hline Pembiayaan Murabahah & 40 & 4.437 .767 & 33.195 .572 & 14.054 .704 \\
DPK & 40 & 10.824 .597 & 55.767 .955 & 29.281 .880 \\
Marjin Keuntungan & 40 & 167.765 & 3.773 .500 & $987.132,7$ \\
SWBI & 40 & 170.000 & 5.988 .000 & 2.576 .154 \\
\end{tabular}

Sumber: Data sekunder, diolah (2014)

Tabel 2

Hasil Analisis Deskriptif (dalam persen)

\begin{tabular}{|l|l|c|c|r|}
\hline \multicolumn{1}{|c|}{ Variabel } & N & Minimum & Maksimum & Rata-rata \\
\hline ROA & 40 & 0,0072 & 0,0281 & 0,019692 \\
NPF & 40 & 0,0202 & 0,0886 & 0,039140 \\
\hline
\end{tabular}

Sumber: Data Sekunder, diolah (2014)

Data deskriptif menunjukkan jumlah data (N) ada 40. Pembiayaan murabahah menunjukkan nilai terkecil (minimum) sebesar Rp4.437.767 dan pembiayaan murabahah terbesar adalah Rp33.195.572 dengan mean sebesar Rp14.054.704. Variabel DPK terkecil (minimum) adalah Rp10.824.597 dan DPK terbesar (maksimum) adalah Rp55.767.955 dengan rata-rata Rp29.281.880. Variabel marjin keuntungan memiliki nilai minimum Rp167.765 dan nilai maksimum sebesar Rp3.773.500 dengan nilai rata-rata Rp987.132,7. Nilai minimum SWBI sebesar Rp170.000, nilai maksimum sebesar Rp5.988.000 dan rata-rata sebesar Rp. 2.576.154. Variabel ROA memiliki nilai minimum 0,0072, maksimum 0,0281 dan rata-rata sebesar 0,019692. Variabel yang terakhir yaitu NPF memiliki nilai minimum sebesar 0,0202, maksimum 0,0886 dan nilai rata-rata sebesar 0,039140. 


\section{Uji Asumsi Klasik}

\section{Uji Heteroskedastisitas}

\section{Gambar 1}

Hasil Uji Heteroskedastisitas

Scatterplot

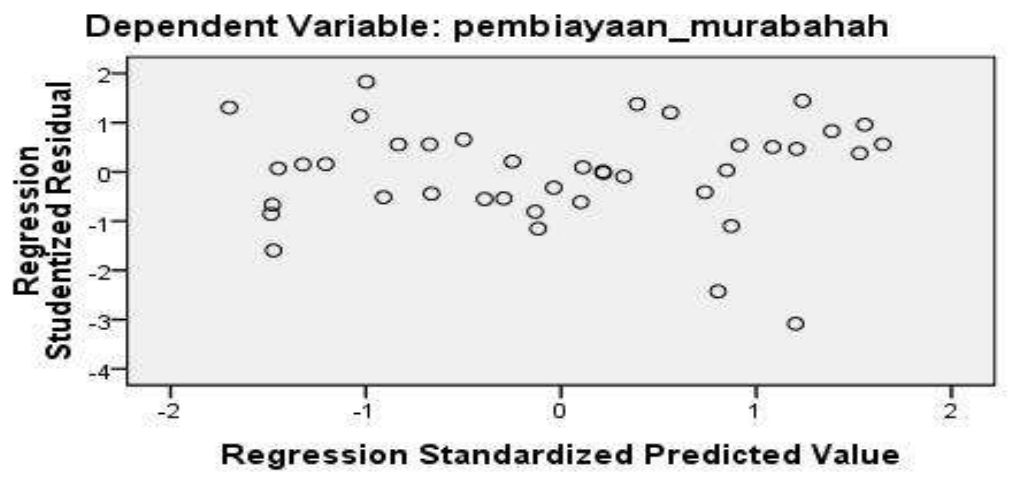

Grafik scatterplot menunjukkan titik-titik menyebar secara acak serta tersebar baik di atas maupun di bawah angka 0 pada sumbu Y. Hal ini dapat disimpulkan bahwa tidak terjadi heteroskedastisitas pada model regresi.

\section{Uji Multikolinearitas}

Tabel 3 menunjukkan nilai tolerance kelima variabel lebih dari 0,10 dan nilai VIF kurang dari 10. Jika nilai tolerance $>0,10$ dan nilai $\mathrm{VIF}<10$, maka dapat disimpulkan bahwa tidak ada multikolinieritas antar variabel independen dalam model regresi.

Tabel 3

\section{Hasil Uji Multikolinieritas}

\begin{tabular}{|l|r|c|}
\hline Variabel Independen & Tolerance & VIF \\
\hline DPK & 0,161 & 6,201 \\
Marjin keuntungan & 0,272 & 3,673 \\
SWBI & 0,442 & 2,262 \\
ROA & 0,802 & 1,246 \\
NPF & 0,379 & 2,636 \\
\hline
\end{tabular}

Sumber: Data sekunder, diolah (2014)

\section{Uji Autokorelasi}

Tabel 4 menunjukkan nilai Durbin-Watson (DW) sebesar 1,933. Nilai DU 
dan DL dapat diperoleh dari tabel statistik Durbin Watson. Nilai DW terletak di antara batas atas atau upper bound $(\mathrm{du})$ dan (4-du) maka koefisien autokorelasi $=0$. Hal ini berarti menunjukkan tidak ada autokorelasi.

Tabel 4

Hasil Uji Autokorelasi

\begin{tabular}{|c|c|}
\hline Model & Durbin-Watson \\
\hline 1 & 1,933 \\
\hline
\end{tabular}

Sumber: Data sekunder, diolah (2014)

\section{Uji Normalitas}

Tabel 5 menunjukkan nilai signifikansi sebesar 0,891, karena signifikansi lebih dari 0,05 maka nilai residual tersebut berdistribusi normal.

Tabel 5

Hasil Uji Normalitas Regresi

\begin{tabular}{|c|r|r|r|}
\hline Sampel & Kolmogorov- Smirnov Z & Signifikansi & Simpulan \\
\hline 40 & 0,579 & 0,891 & Signifikan \\
\hline
\end{tabular}

Sumber: Data sekunder, diolah (2014)

\section{Uji Hipotesis}

\section{Uji Determinasi $\left(\mathbf{R}^{2}\right)$}

\begin{tabular}{|c|c|}
\multicolumn{1}{c}{ Tabel 6 } \\
Uji $\left(\mathbf{R}^{2}\right)$ \\
\hline Model & Adjusted R Square \\
\hline 1 & $\mathbf{0 , 9 8 7}$ \\
\hline
\end{tabular}

Sumber: Data sekunder, diolah (2014)

Tabel 6 menunjukkan nilai adjusted $\mathrm{R}^{2}$ sebesar 0,987. Hal ini berarti 98,7\% variasi pembiayaan murabahah dapat dijelaskan oleh variasi dari ke lima variabel independen yaitu DPK, marjin keuntungan, SWBI, ROA dan NPF, sedangkan sisanya dipengaruhi oleh variabel lain yang tidak dimasukkan dalam model ini. 


\section{Uji Signifikansi Simultan (uji F)}

Tabel 7

Hasil Uji F

\begin{tabular}{|r|r|c|}
\hline \multicolumn{1}{|l|}{ F hitung } & F tabel & Keterangan \\
\hline 591,332 & 2,49 & Menerima Ha \\
\hline
\end{tabular}

Sumber: Data sekunder, diolah (2014)

Berdasar hasil dari uji $\mathrm{F}$ dapat dilihat nilai $\mathrm{F}$ hitung 591,332 lebih besar dari nilai $\mathrm{F}$ tabel yaitu sebesar 2,49 sehingga dapat disumpulkan bahwa variabel DPK, marjin keuntungan, SWBI, ROA, dan NPF secara simultan berpengaruh terhadap pembiayaan murabahah.

\section{Uji Signifikansi Parameter Individual (uji t)}

Tabel 9

\section{Hasil Uji t}

\begin{tabular}{|l|r|r|l|}
\hline \multicolumn{1}{|c|}{ Variabel } & \multicolumn{1}{c|}{ T } & \multicolumn{1}{c|}{ t tabel } & \multicolumn{1}{|c|}{ Keterangan } \\
\hline DPK & 25,501 & 1,69092 & Menerima $\mathrm{H}_{1}$ \\
\hline Marjin keuntungan & $-0,810$ & 1,69092 & Menolak $\mathrm{H}_{2}$ \\
\hline SWBI & $-5,110$ & $-1,69092$ & Menerima $\mathrm{H}_{3}$ \\
\hline ROA & 3,666 & 1,69092 & Menerima $\mathrm{H}_{4}$ \\
\hline NPF & 2,886 & $-1,69092$ & Menolak $\mathrm{H}_{5}$ \\
\hline
\end{tabular}

Sumber: Data sekunder, diolah (2014)

1) Uji hipotesis pengaruh DPK terhadap pembiayaan murabahah

Hasil uji diperoleh nilai t hitung 25,501 lebih besar dari t tabel sebesar 1,69092 dengan nilai koefisien beta dengan arah positif sebesar 1,442 yang menunjukkan bahwa variabel DPK berpengaruh positif terhadap pembiayaan murabahah, sehingga $\mathrm{H}_{1}$ diterima.

2) Uji hipotesis pengaruh marjin keuntungan terhadap pembiayaan murabahah

Hasil uji diperoleh nilai $\mathrm{t}$ hitung $-0,810$ lebih kecil dari $\mathrm{t}$ tabel sebesar 1,69092 dengan nilai koefisien beta dengan arah negatif sebesar -0,024 yang menunjukkan bahwa variabel marjin keuntungan berpengaruh negatif terhadap pembiayaan murabahah, sehingga $\mathrm{H}_{2}$ ditolak. 
3) Uji hipotesis pengaruh SWBI terhadap pembiayaan murabahah

Hasil diperoleh nilai t hitung -5,110 lebih besar dari t tabel sebesar -1,69092 dengan nilai koefisien beta dengan arah negatif sebesar -0,123 yang menunjukkan bahwa variabel SWBI berpengaruh negatif terhadap pembiayaan murabahah, sehingga $\mathrm{H}_{3}$ diterima.

4) Uji hipotesis pengaruh ROA terhadap pembiayaan murabahah

Hasil diperoleh nilai t hitung 3,666 lebih besar dari t tabel sebesar 1,69092 dengan nilai koefisien beta dengan arah positif sebesar 9,286 yang menunjukkan bahwa variabel ROA berpengaruh positif terhadap pembiayaan murabahah, sehingga $\mathrm{H} 4$ diterima.

5) Uji hipotesis pengaruh NPF terhadap pembiayaan murabahah

Hasil diperoleh nilai t hitung 2,886 lebih besar dari t tabel sebesar -1,69092 dengan nilai koefisien beta dengan arah positif sebesar 3,676 yang menunjukkan bahwa variabel NPF berpengaruh positif terhadap pembiayaan murabahah, karena tidak sejalan dengan hipotesis maka H5 ditolak.

\section{SIMPULAN, KETERBATASAN, DAN SARAN}

Simpulan dari penelitian ini adalah DPK, NPF, dan ROA berpengaruh positif terhadap pembiayaan murabahah. Sementara itu, variabel SWBI berpengaruh negatif terhadap pembiayaan murabahah. Variabel marjin keuntungan tidak berpengaruh terhadap pembiayaan murabahah.

Penelitian ini masih terdapat keterbatasan yang menyebabkan hasil penelitian masih sangat minim, yaitu:

1. Masih sedikit literatur yang berkaitan dengan variabel penelitian sehingga sulit peneliti sulit menjelaskan variabel lebih rinci.

2. Masih sedikitnya penelitian (jurnal) yang berkaitan dengan penelitian ini.

3. Penelitian ini menggunakan analisis regresi berganda, analisis ini memiliki keterbatasan dan kelemahan, antara lain tidak mampu menunjukkan titik jenuh fungsi yang sedang diteliti, akibatnya selalu timbul kemungkinan kesalahan prediksi.

Berdasar keterbatasan yang ada, maka disarankan untuk menambah variabel 
baik dari faktor eksternal maupun faktor internal bank misalnya dari faktor eksternal bank antara lain perubahan teknologi pengiriman jasa, kompetisi dari lembaga keuangan lainnya, hukum dan peraturan mengenai lembaga keuangan, dan kebijakan pemerintah yang mempengaruhi sistem ekonomi dan keuangan. Faktor internal bank bisa dilihat dari rasio keuangan, seperti ROE, FDR, CAR, dan lainlain. Menambah perioda lebih banyak dan memperluas objek riset agar mendapatkan hasil yang lebih baik.

\section{DAFTAR PUSTAKA}

Basyarah, Ahmad, Azfar. 2013. Analisis Faktor-faktor yang Mempengaruhi Pembiayaan Murabahah (Studi Kasus PT. Bank Muamalat Indonesia tbk.). Skripsi. Yogyakarta: Universitas Muhammadiyah Yogyakarta.

Fanafian, Anintio. 2012. Analisis Faktor-Faktor yang Mempengaruhi Pembiayaan Murabahah Bank Umum Syariah di Indonesia (Perioda Mei 2007-April 2012) . Skripsi. Yogyakarta: Universitas Muhammadiyah Yogyakarta.

Ghozali, Imam. 2011. Aplikasi Analisis Multivariate dengan Program IBM SPSS 19, Edisi 5. Semarang: Universitas Diponegoro.

Ismoyowati, Ayu. 2013. Analisis Faktor-Faktor yang Berpengaruh terhadap Pembiayaan Murabahah (Studi Kasus Bank Umum Syariah Tahun 20082012). Skripsi. Yogyakarta: Universitas Muhammadiyah Yogyakarta.

Maula, Khodijah dan Hadiyyatul. 2008. Pengaruh DPK, Modal Sendiri, Margin Keuntungan dan NPF terhadap Pembiayaan Murabahah pada Bank Syariah Mandiri. Skripsi. Yogyakarta: UIN Sunan Kalijaga.

Nurbaya, Ferial. 2013. Analisis Pengaruh CAR, ROA, dan Dana Pihak Ketiga (DPK) terhadap Pembiayaan Murabahah Perioda Maret 2001 - Desember 2009 (Studi Kasus pada PT Bank Muamalat Indoesia,Tbk.). Skripsi. Semarang: Universitas Diponegoro.

Nurapriyani, Dwi. 2009. Faktor-Faktor yang Mempengaruhi Pembiayaan Murabahah di Bank Syariah Mandiri Perioda Tahun 2004-2007. Skripsi. Yogyakarta: UIN Sunan Kalijaga.

Octavina, Kristia. 2011. Pengaruh Kas, Bonus SWBI, Margin Keuntungan, dan 
Dana Pihak Ketiga terhadap Pembiayaan Murabahah (Studi Empiris pada Bank Umum Syariah di Indonesia Perioda 2008-2010). Skripsi. Yogyakarta: Universitas Muhammadiyah Yogyakarta.

Pratami, W.A.N. 2011. Analisis Pengaruh Dana Pihak Ketiga, Capital Adequacy Ratio (CAR), Non Performing Financing (NPF), dan Return On Asset (ROA) Terhadap Pembiayaan pada Perbankan Syariah (Studi Kasus pada Bank Muamalat Indonesia Perioda 2001-2011). Skripsi. Semarang: Universitas Diponegoro.

Saputro, Riza, Halim. 2012 Pengaruh Dana Pihak Ketiga, Non Performing Financing, Return on Asset dan Bagi Hasil terhadap pembiayaan (Studi Kasus Bank Umum Syariah Perioda 2007-2011). Skripsi. Yogyakarta: UIN Sunan Kalijaga.

Franedya, Roy, 2010, pembiayaan murabahah masih dominan. Didapatkan: http://www.contan.co.id/06/14[5 Mei 2014].

Undang-undang nomor 2/9/PBI/2000 tentang Sertifikat Wadiah Bank Indonesia [online] didapatkan: http://www.mail-archive.com[16>Mei 2014.

Wibawa, Aninditya, Annisa. 2013. Lima Bank Syariah dengan Laba terbesar [online]. Didapatkan: $<$ http://keuangan.kontan.co.id [25 $>$ Mei 2014. 